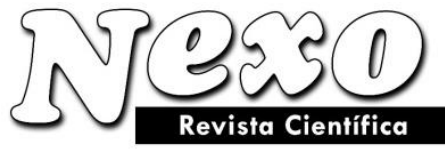

Universidad Nacional de Ingeniería COPYRIGHT $\odot$ (UNI). TODOS LOS DERECHOS RESERVADOS

http://revistas.uni.edu.ni/index.php/Nexo https://doi.org/10.5377/nexo.v33i02.10804

Vol. 33, No. 02, pp. 725-736/Diciembre 2020

(c) (i) $(9$

\title{
Evaluation of meliloti rhizobium activity effectiveness on quantitative properties of alfalfa by bacterial inoculation in the south-east of Iran
}

\section{Evaluación de la eficacia de la actividad de Meliloti Rhizobium sobre las propiedades cuantitativas de la alfalfa por inoculación bacteriana en el sudeste de Irán}

\author{
Hojjat Safari Kamal Abadi ${ }^{1}$, Ali Reza Valad Abadi ${ }^{*}$, Jahanfar Daneshian ${ }^{2}$, Hossien Heydari \\ Sharif Abad $^{3}$, Amin Baghizadeh ${ }^{3}$
}

${ }^{1}$ Department of Agronomy, Takestan Branch, Islamic Azad University, Takestan, Iran.

${ }^{2}$ Seed and Plant Improvement Institute, Agricultural, Research Education Extension Organisation Iran, Iran.

${ }^{3}$ Department of Agronomy, Science and Research Branch, Islamic Azad University, Tehran, Iran.

${ }^{3}$ Department of Biotechnology, Institute of Science and High Technology and Environmental Sciences, Graduate University of Advanced Technology, Kerman, Iran.

Corresponding author email: dr.valadabady@yahoo.com

(recibido/received: 16-July-2020; aceptado/accepted: 19-September-2020)

\begin{abstract}
In order to investigate the effect of bacterial inoculation on yield, chlorophyll and protein content of alfalfa to obtain economically experimental products in Shahid Zande Rouh Agricultural Training Center in Kerman as a split plot in time based on a completely randomized block design with four replications on the ground Which had not been done before, was done. Bacterial inoculation was at three levels (Rhizobium meliluti, Rhizobium leguminasarum and no inoculation as a control). Bacterial inoculation had a significant effect on all studied traits and caused an increase in chlorophyll content, yield and protein percentage. In terms of fresh forage weight, the first and third crops had the highest yield with the application of Rhizobium meliloti (6 tons per hectare). The highest percentage of protein related to inoculation of Rhizobium meliloti was observed in the second Picking. According to the results of this study, inoculation with Rhizobium meliloti bacteria increases the ability of nitrogen fixation 3 to 4 times compared to the control and improved the alfalfa traits of Bami cultivar in southeastern Iran.
\end{abstract}

Keywords: Alfaalfa, Rhizobium, Picking, Bacterial Inoculation. 


\section{RESUMEN}

Con el fin de investigar el efecto de la inoculación bacteriana en el rendimiento, el contenido de clorofila y proteína de la alfalfa para obtener productos experimentales económicos en el Centro de Capacitación Agrícola Shahid Zande Rouh en Kerman como una parcela dividida en el tiempo basado en un diseño de bloques completamente al azar con cuatro repeticiones en el Terreno que no se había hecho antes, se hizo. La inoculación bacteriana se realizó en tres niveles (Rhizobium meliluti, Rhizobium leguminasarum y sin inoculación como control). La inoculación bacteriana tuvo un efecto significativo en todos los rasgos estudiados y provocó un aumento en el contenido de clorofila, rendimiento y porcentaje de proteína. En términos de peso del forraje fresco, el primer y tercer cultivo tuvieron el mayor rendimiento con la aplicación de Rhizobium meliloti (6 toneladas por hectárea). El mayor porcentaje de proteína relacionado con la inoculación de Rhizobium meliloti se observó en el segundo Picking. Según los resultados de este estudio, la inoculación con la bacteria Rhizobium meliloti aumenta la capacidad de fijación de nitrógeno de 3 a 4 veces en comparación con el control y mejoró los rasgos de alfalfa del cultivar Bami en el sureste de Irán.

Palabras clave: Alfaalfa, Rhizobium, Picking, Inoculación bacteriana.

\section{INTRODUCTION}

Forage plants of the legume family have been considered worldwide due to their higher protein content and the effect of these plants on soil fertility due to their ability to coexist with rhizobim (Gunes et al., 2008). One of the most important forage plants is alfalfa, forage alfalfa It is a member of the legume family. Consumption of this product is very important due to its high quality and food reserves. The development of fodder crops, especially alfalfa, in addition to providing food needed for livestock for agriculture and preservation of natural resources and economy of each region is important (Taherkhani et al., 2009). Due to the coexistence of the plant with the nitrogen-fixing bacteria Rhizobium meliloti, alfalfa is expected to receive most of its nutritional needs through bacteria. Nitrogen fixation in soil causes its cultivation to be favorable for crop rotation (Fukami et al., 2018).

Bacterial inoculation can eliminate the harmful effects of plant pathogens and living and nonliving environmental stresses. In Iran, the area of soils affected by nutrient deficiencies and excessive fertilizer consumption is over $50 \%$ of the total agricultural land. Nitrogen fixation and inoculation increasing yield (Aslani et al., 2011; Abusuwar \& Daur, 2015).

In the last few decades, the use of chemical inputs in agricultural lands has caused environmental problems such as contamination of water resources, the quality loss of agricultural products, and reduced soil fertility (Ensiye et al., 2018). The use of nitrogen fertilizers to increase crop production will continue for the foreseeable future, but more attention should be given to the biological stabilization of nitrogen by microorganisms in order to reduce their use. Rhizobium bacterium inside the tuber or node produced on the plant root receives air nitrogen, stabilizes it, and converts it to $\mathrm{NH}_{3}$, the product of which is used both by the bacterium itself and the host plant. Proliferation of $R$. bacteria around the root of Leguminosas can increase the absorption of elements such as phosphorus, potassium, calcium, and iron (Amri et al., 2010).

Rhizobium inoculation not only increases effective root tubers but also the grain yield and has a positive effect on increasing biological nitrogen fixation and alfalfa yield.

In a study on faba bean, it was observed that inoculation with Azotobacter and Rhizobium significantly increased total aerial part dry weight in comparison with control treatment. Of the sixteen nutrients required by plants, seven elements are iron, zinc, manganese, boron, copper, molybdenum, and chlorine. These elements play a role in increasing production after balancing 
the use of nitrogen, phosphate, and potassium fertilizers. In Iran, the deficiency of micronutrients, especially zinc, manganese, and boron, is common in farms and gardens due to decreased soil organic matter content, the presence of carbonate and bicarbonate ions in irrigation water, and the high consumption of phosphorus (Yang et al., 2013).

In an experiment, the effect of Rhizobium was investigated on the amounts of absorbed elements. Deficiency of nutrients decreased the amounts of elements in leaves and roots of non-inoculated plants (control), but nutrient deficiency was observed only in the leaves of plants inoculated with Rhizobium and the elements remained unchanged in the roots. In the absence of nutrient deficiencies, the uptake of trace elements increased significantly in alfalfa inoculated by bacteria (Dordas, 2009). It seems that by performing this experiment and inoculating nitrogen-fixing bacteria, while enhancing the growth of the crop, it can also increase the yield and can also play a role in controlling the pathogens, and follow the path to organic and sustainable agriculture (Hu et al., 2013).

\section{MATERIALS AND METHODS}

The effects of bacterial inoculation on chlorophyll content, protein content, and the yield of alfalfa, was investigated in an experiment as a split-split plot in time based on randomized complete block design with four replications in Shahid Zandeh-Roh Agricultural Training Center of Kerman (10 km Jupar Road) located at $25^{\circ}$ and $32^{\prime} \mathrm{N}$ and $53^{\circ}$ and $29^{\prime} \mathrm{E}$ with an altitude of $1755 \mathrm{~m}$ in growing season in 2013. According to the soil test results, no cultivation was carried out previously in the studied land, and there was a nutrient deficiency. Hence, a foliar application was provided and implemented in order to provide the nutrient elements according to (Table 1).

Experimental factors included foliar application of micronutrient spraying using biomethane branded chelate fertilizer at five levels including spraying of iron chelate, zinc chelate, manganese chelate, iron + zinc + manganese mixture, and no spraying (as a control). At a concentration of four per thousand as the main factor, bacterial inoculation was as a sub factor at three levels (Rhizobium meliloti, R. leguminosarum, and non-inoculation or the control) and the number of alfalfa crop was considered as a sub-factor.

Seeds of alfalfa beam from Bam seed were prepared from Kerman Agricultural Jihad Organization. Seeds were washed with $70 \%$ ethanol for two minutes and then by $1 \%$ sodium hypochlorite for 5 minutes, followed by three times with distilled water. Sterilized alfalfa seeds were immersed in vacuum for one hour at ambient temperature to facilitate penetration of bacterial strains into the seeds through the pores. Control seeds were also placed under similar conditions. Bacterial inoculation was performed using $R$. meliloti and $R$. leguminosarum. Inoculation was carried out as seed. For this purpose, the seeds were impregnated in a prepared $10 \%$ solution of diluted sugar water, with an optimum concentration of of $110 \mathrm{ml} / \mathrm{cfu}$ to stimulate alfalfa growth. Bacteria were obtained from the laboratory of the Faculty of Agriculture, Shahid Bahonar University of Kerman, and inoculated seeds were immediately cultured on May 5, 2013.

Immediately after sowing, the first irrigation was carried out as leakage, and after regular germination, irrigation was continued once every seven days. Weeding was done manually. No disease or pest was observed on the farm during the growing season. Foliar application of each plot was performed individually based on experimental treatments when the plants were 10-15 $\mathrm{cm}$ long before flowering stage at early hours of the morning and sometimes in late hours of the 
day before complete darkness. Forage was harvested at a time when 5-10\% of the bushes were flowering in the field. For sampling in each experimental plot, first two rows of side and $0.5 \mathrm{~m}$ from the top and bottom were considered as margins. The evaluated traits were chlorophyll content, protein percentage, and forage yield (ton/ha), in aerial parts. The experimental alfalfa produced four crops during the crop year and sampling was performed to evaluate traits in all the four crops.

To measure chlorophylls a and $\mathrm{b}$ and total at flowering stage, $0.5 \mathrm{~g}$ of the leaf was developed and $80 \%$ acetone solvent and spectrophotometer were used. The following equations were used to calculate chlorophyll concentrations (mg/g fresh leaf) (Delić et al., 2016):

Chl.a $=(12.7(\mathrm{~A} 663)-2.69(\mathrm{~A} 645)) \mathrm{V} / \mathrm{W} \times 1000$

Chl.b $=(22.9(\mathrm{~A} 645)-4.68(\mathrm{~A} 663)) \mathrm{V} / \mathrm{W} \times 1000$

Chl.total $=$ Chl. $\mathrm{a}+$ Chl.b

In these relationships, A663 and A645 are absorbance at at $663 \mathrm{~nm}$ and $645 \mathrm{~nm}$, respectively, V is soluble volume, and $\mathrm{W}$ is leaf fresh weight $(\mathrm{mg})$.

To measure the protein, the leaf powder was boiled in concentrated sulfuric acid in the presence of boiling copper ion so that nitrogen turns into ammonia. For each mole of hydrochloric acid, there was $14 \mathrm{~g}$ of nitrogen in the primary tissue. Protein content was measured using a coefficient of 6.25 (Ahemad \& khan Khan, 2011).

In order to obtain the dry weight after chopping the plants and mixing them, two hundred samples were selected and placed in a dryer (ironing machine) at a temperature of $75^{\circ} \mathrm{C}$ until reaching a constant weight. The fresh weight of alfalfa after harvest, It was immediately identified in the field by a digital scale with an accuracy of $0.01 \mathrm{~g}$ (Ahemad \& khan Khan, 2011). Data were analyzed using SAS statistical software and mean values were compared using Duncan's multiple range test at at $5 \%$ level of probability.

\section{RESULTS AND DISCUSSION}

\section{Chlorophyll a}

The results showed that the highest amount of chlorophyll a was related to Mn foliar application and $R$. leguminosarum inoculation with $45.25 \mathrm{mg} / \mathrm{g}$ and the lowest one belonged to inoculation with $R$. meliloti and Mn foliar application of $26.24 \mathrm{mg} / \mathrm{g}$ (Table 3).

The results of the mutual effects of micronutrient and crop in each crop showed that the highest $(47.17 \mathrm{mg} / \mathrm{g})$ and the lowest $(27.94 \mathrm{mg} / \mathrm{g})$ amounts of chlorophyll a were related to the lack of foliar application and foliar application of iron in the second crop and the first crops, respectively (Table 4).

The increase in chlorophyll a content was higher due to the use of micronutrients, especially manganese. Increased plant chlorophyll content as a result of using micronutrients was also reported by Aslani et al. A decrease in chlorophyll concentration under nutrient deficiency appears to be due to the effects of chlorophyllase peroxidase and phenolic compounds resulting from the degradation of chlorophyll (Delic et al., 2016). Application of Pseudomonas bacteria in beans in the absence of nutrient deficiencies increased the level of chlorophyll a. (Dordas et al., 2009). In this experiment, an increase in chlorophyll A content was observed as a result of using micronutrients, in particular manganese. Increased plant chlorophyll content as a result of using micronutrients was reported by Daneshian (2012).

\section{Chlorophyll b}


The results of ANOVA for the effects of test factors on the traits examined are presented in (Table 2). The highest (44.2 mg) and the lowest $(20.07 \mathrm{mg}$ ) amounts of chlorophyll b were recorded in the foliar application of $\mathrm{Mn}$ and iron, respectively. Application of bacteria and micronutrients had no significant effects on chlorophyll b contents (Table 4). Decreased membrane proteins and increased activity of chlorophyllase and peroxidase enzymes are among the factors affecting chlorophyll reductions in lack of insemination conditions. A decline in leaf vegetation under long-term nutrient deficiency is partly due to a decrease in nitrogen flow into the tissue and a change in nitrate reductase activity. As reported by Hadi (2009), concentrations of chlorophylls A and B decreased in wheat by $38 \%$ and $35 \%$ on average, respectively, in the first year. One of the most important reasons for the reduction of chlorophyll B is its degradation by reactive oxygen species (ROS). A decrease in photosystem II activity, reduction of Rubisco enzyme activity, and inhibition of ATP synthesis result in increased free oxygen formation in chloroplasts, and further degradation of chlorophyll $\mathrm{B}$ reduces its concentrations relative to chlorophyll A, which was also observed by (Hadi et al., 2009).

\section{Total chlorophyll}

The highest amount total chlorophyll $(53.99 \mathrm{mg})$ was found in Mn foliar application and noninoculation and the lowest level $(37.90 \mathrm{mg} / \mathrm{g})$ was measured in Mn foliar application with $R$. meliloti inoculation (Table 3). This result is in line with the results of a study on wheat by Monez in 2006. Studies show that the bacteria play an important role in improving the uptake and growth of the root, which in turn absorbs most of the elements involved in chlorophyll such as magnesium, manganese, and zinc through the root adsorption process. Previous studies show an important role of bacteria in improving the root uptake and growth, which in turn increases more absorption of such elements as iron and manganese involved in chlorophyll synthesis. The present study also demonstrated that nutrient depletion and deficiency stimulate senescence (leaf yellowing), resulting in a decrease in total chlorophyll, which is consistent with a research on wheat conducted by Eltegani \& Rahman (Abdel-Rahman, 2013).

\section{Protein percentage}

The highest protein percentage was observed in $\mathrm{Mn}$ and $R$. meliloti in the fourth crop and the least $(22.60 \%$ ) level was detected in $\mathrm{Zn}$ spraying and inoculation in the first crop (Table 6). The results showed that protein levels were higher in second and fourth crops. The reason for this can be explained by the fact that more Rhizobium immobilization and more nutrients are available to the plant, and the bacteria present in biofertilizers increase the absorption of other nutrients and dissolve minerals. Similar results were reported by Khalil et al.

Salter 2014 stated that an increase in nitrogen content significantly increased wheat grain protein content. In addition to the leaf area index, bacterial inoculation and further stabilization of the plant in nutrient uptake associated with leaf production seem to be involved in protein elevation in the second and fourth crops of this research. In fact, it can be speculated that improvements in quantitative indices (e.g. fresh forage yield) lead to increases in qualitative traits, such as protein content, as the plant is provided with more nutrients along with more nitrogen fixation as a result of inoculation, which is in line with that of Ardakani (Khalil et al., 2010).

\section{Function}


The results showed that the highest function $\left(71.25 \mathrm{~g} / \mathrm{m}^{2}\right)$ was related to the fourth crop and no foliar application, and the lowest one $\left(42.17 \mathrm{~g} / \mathrm{m}^{2}\right)$ was found in the foliar application of $\mathrm{Zn}+$ Mn in the second crop (Table 4).

According to the present results of inoculation, the highest level $\left(67.75 \mathrm{~g} / \mathrm{m}^{2}\right)$ was observed in foliar application of $R$. leguminosarum in the third crop, and the lowest amount $\left(65.45 \mathrm{~g} / \mathrm{m}^{2}\right)$ belonged to inoculation with $R$. meliloti in the first crop (Table 5). There were significant differences between the control and the other treatments in the foliar application. The increase in height can be attributed to the positive role of organic fertilizers, increased nitrogen efficiency, and greater nutrient availability. Over time, cytokinin production appears to stimulate plant height growth with increase cell division. Temperature changes have a direct impact on the amount of forage in different crops, and can also reduce forage production by reducing nutrients in early crops.

The highest rate of forage production was measured in the fourth crop, which is apparently because the plant spent longer growth period and the temperature conditions was favorable for the crop during this period resulting in the maximum production of forage. Loss of dry weight is probably a consequence of a decrease in the net crop yield, which decreases the share of different organs of juice, and consequently reducing the plant weight. A decrease in photosynthesis reduces the amount of chlorophyll and the nitrogen metabolism pathway in the synthesis of compounds, such as proline, used for osmotic regulation, which causes nutrient imbalance and consequently diminishes function. In an experiment on alfalfa, it was found that nutrient restriction at flowering time reduced photosynthetic material transfer and thus affected the function (Tiedje et al., 1982).

\section{Total fresh weight of the plant}

The highest amount (75 g per plant) of Mn foliar application was recorded in inoculation with $R$. meliloti in the first crop (Table 7).

$R$. meliloti bacteria were reported to increase the aerial part fresh weight compared to control treatment.

In this study, it seems that the lack of water in Kerman region and consequently absorption of nutrients result in the weight loss. Water deficiency disrupts the electron transport system and induces antioxidant activities in chlorine, platelet, and mitochondria. In this study, fresh weight elevated further in the fourth crop due to better balance of nutrients and increased leaf development, as well as elevated turgescence and photosynthesis. Temperature fluctuations seem to have a direct effect on fresh forage yield in different crops. Also, the deficiency of root nutrients in the first crop and its increase in the final crops could reduce forage production by creating nutritional stress. The first harvest was reported to have the lowest fresh forage production.

\section{Stem fresh weight}

The highest amount (89.44 g) of stem fresh weight was found in $\mathrm{Zn}$ foliar application and $R$. leguminosarum inoculation with and the lowest level $(33.25 \mathrm{~g})$ was recorded in Fe spraying and R. meliloti inoculation with (Table 3).

The highest amount $\left(1267 \mathrm{~g} / \mathrm{m}^{2}\right)$ of non-foliar application occurred in the fourth crop and the lowest level $\left(672 \mathrm{~g} / \mathrm{m}^{2}\right)$ was obtained in Mn foliar application in the first crop (Table 4). In this study, the effect of fresh weight in the fourth crop appears to be due to better nutrient balance and increased leaf development as well as increased turgor to increase photosynthesis. 
The highest $(78.18 \mathrm{~g})$ inoculation of $R$. leguminosarum was detected in the second crop and the lowest (35.10 g) was noticed in $R$. meliloti in the fourth crop (Table 5).

In this study, water absorption resulted in better nutrient uptake, and nutrient deficiency was inhibited by the growth and development, resulting in decreased cell growth and reduced body weight due to reduced photosynthesis. The growth and differentiation of cells depends on the absorption of nutrients and water (McKenzie et al., 2015; Delic et al., 2016).

\section{Aerial part (leaf) fresh weight}

The highest effect $(25.77 \mathrm{~g})$ of foliar application was on inoculation of $R$. Leguminosarum and the least effect ( $8.24 \mathrm{~g}$ ) was observed in iron and $R$. meliloti (Table 3). The results showed that $R$. leguminosarum inoculation had the highest effect in the third crop and the least impact belonged to $R$. meliloti inoculation in the first crop (Table 5). It seems that the increased leaf weight is due to its length and width justification. This conclusion can be explained by the effect of dietary $\mathrm{Zn}$ on cell division by increasing auxin, which increases leaf length and width. In this experiment, leaf weight reached its maximum after germination until pollination, thereby resulting in increasing photosynthesis and total dry weight of the plant, which restricted leaf growth and development under lack of insemintaion.

Table 1: Field soil characteristics

\begin{tabular}{|c|c|c|c|c|c|c|c|c|c|}
\hline \multirow{2}{*}{ Soil } & \multirow{2}{*}{$\mathrm{pH}$} & \multirow{2}{*}{$\begin{array}{c}\mathrm{EC} \\
(\mathrm{ds} / \mathrm{m})\end{array}$} & \multirow{2}{*}{$\begin{array}{c}\mathrm{K} \\
(\mathrm{ppm})\end{array}$} & \multirow{2}{*}{$\begin{array}{c}\mathrm{P} \\
(\mathrm{ppm})\end{array}$} & \multirow{2}{*}{$\begin{array}{c}\text { Total } \\
\% \mathrm{~N}\end{array}$} & $\mathrm{Zn}$ & $\mathrm{Fe}$ & \multirow{2}{*}{$\% \mathrm{OC}$} & \multirow{2}{*}{ Depth $(\mathrm{cm})$} \\
\hline & & & & & & \multicolumn{2}{|c|}{$\mathrm{mg} / \mathrm{kg}$} & & \\
\hline (Sandy-Loam) & 7.5 & 1.64 & 100 & 6.5 & 0.31 & 0.65 & 2.6 & 0.48 & $0-30$ \\
\hline (Sandy-Loam) & 7.6 & 2.01 & 175 & 4.2 & 0.39 & 0.92 & 4.2 & 0.8 & $30-60$ \\
\hline
\end{tabular}

Table 2: Analysis of variance of studied traits in alfalfa

\begin{tabular}{|c|c|c|c|c|c|c|c|c|c|c|}
\hline $\begin{array}{c}\text { Source } \\
\text { of } \\
\text { variatio } \\
n\end{array}$ & df & $\begin{array}{c}\text { Chlorop } \\
\text { hyl a }\end{array}$ & $\begin{array}{c}\text { Chlorop } \\
\text { hyl b }\end{array}$ & $\begin{array}{c}\text { Total } \\
\text { Chlorop } \\
\text { hyl }\end{array}$ & $\begin{array}{c}\text { Protein } \\
(\%)\end{array}$ & Yield & $\begin{array}{l}\text { Total } \\
\text { shrub }\end{array}$ & $\begin{array}{c}\text { Aerial } \\
\text { Fresh } \\
\text { Weight }\end{array}$ & $\begin{array}{c}\text { Stem Wet } \\
\text { Weight }\end{array}$ & $\begin{array}{c}\text { Leaf } \\
\text { Fresh } \\
\text { Weight }\end{array}$ \\
\hline $\begin{array}{c}\text { Replicat } \\
\text { ion }\end{array}$ & 3 & $5.11 \mathrm{~ns}$ & $\begin{array}{c}1577.93 * \\
*\end{array}$ & $25.766 \mathrm{~ns}$ & $\begin{array}{c}34.075 \\
\text { ns }\end{array}$ & $\begin{array}{c}1267.53 \\
* *\end{array}$ & $\begin{array}{c}613.67 \\
n s\end{array}$ & $\begin{array}{c}174.745 \\
\text { ns }\end{array}$ & $\begin{array}{c}296.636 \\
\text { ns }\end{array}$ & $\begin{array}{c}0.497 \\
\text { ns }\end{array}$ \\
\hline $\begin{array}{c}\text { Nutritio } \\
\text { us }\end{array}$ & 4 & $1009 * *$ & $4864.5 * *$ & $373.09 * *$ & $\begin{array}{c}3566.08 * \\
*\end{array}$ & $\begin{array}{c}922.42 * \\
*\end{array}$ & $\begin{array}{c}1973.64 \\
* *\end{array}$ & $92.946 \mathrm{~ns}$ & $\begin{array}{c}1860.876 \\
* \\
\end{array}$ & $1.786 *$ \\
\hline Error A & 12 & 2.220 & 163.266 & 13.922 & 11.620 & 159 & 2008.16 & 177.857 & 520.992 & 0.611 \\
\hline $\begin{array}{c}\text { Bacteria } \\
\text { (B) }\end{array}$ & 2 & $131.77 * *$ & $\begin{array}{c}1077.75 \\
n s\end{array}$ & $531.43 * *$ & $\begin{array}{c}1350295 \\
* *\end{array}$ & $665.1 * *$ & $\begin{array}{c}1240.41 \\
* *\end{array}$ & $\begin{array}{c}2341.662 \\
* *\end{array}$ & $\begin{array}{c}22607.298 \\
* *\end{array}$ & $\begin{array}{c}24.508 * \\
*\end{array}$ \\
\hline $\begin{array}{c}\text { AB } \\
\text { Nutritio } \\
\text { us } \times \\
\text { Bacteria } \\
\end{array}$ & 8 & $38 * *$ & $732.97 \mathrm{~ns}$ & $230.83 * *$ & $28.915 * *$ & $89.3 \mathrm{~ns}$ & $570.10 *$ & $312.371 *$ & $\begin{array}{c}2070.657 * \\
*\end{array}$ & $\begin{array}{c}0.632 \\
\mathrm{~ns}\end{array}$ \\
\hline Error B & 30 & 9.168 & 405.008 & 7.350 & 0.573 & $\begin{array}{c}1046.69 \\
7\end{array}$ & 115.92 & 132.136 & 428.968 & 0.482 \\
\hline Picking & 3 & $188.8 * *$ & $928.15 \mathrm{~ns}$ & $1042.5 * *$ & $\begin{array}{c}91.0592 * \\
*\end{array}$ & $\begin{array}{c}2755.1 * \\
*\end{array}$ & $226.5 \mathrm{~ns}$ & $114.162 *$ & $810.689 * *$ & $0.207 * *$ \\
\hline $\begin{array}{c}\mathrm{AC} \\
\text { Nutritio } \\
\text { us } \times \\
\text { Picking } \\
\end{array}$ & 12 & $41.5^{* *}$ & $456 \mathrm{~ns}$ & $0.84 \mathrm{~ns}$ & $34.804 * *$ & $\begin{array}{c}177.31 * \\
*\end{array}$ & $\begin{array}{c}360.59 \\
\mathrm{~ns}\end{array}$ & $65.617 \mathrm{~ns}$ & $894.872 * *$ & $0.14 \mathrm{~ns}$ \\
\hline $\begin{array}{c}\text { BC } \\
\text { Bacteria }\end{array}$ & 6 & $6.81 \mathrm{~ns}$ & $276.18 \mathrm{~ns}$ & $0.08 \mathrm{~ns}$ & $2.680 * *$ & $205.55 *$ & $\begin{array}{c}278.27 \\
\text { ns }\end{array}$ & $\begin{array}{c}196.474 * \\
*\end{array}$ & $\begin{array}{c}1350.692 * \\
*\end{array}$ & $\begin{array}{c}0.007 \\
\text { ns }\end{array}$ \\
\hline
\end{tabular}




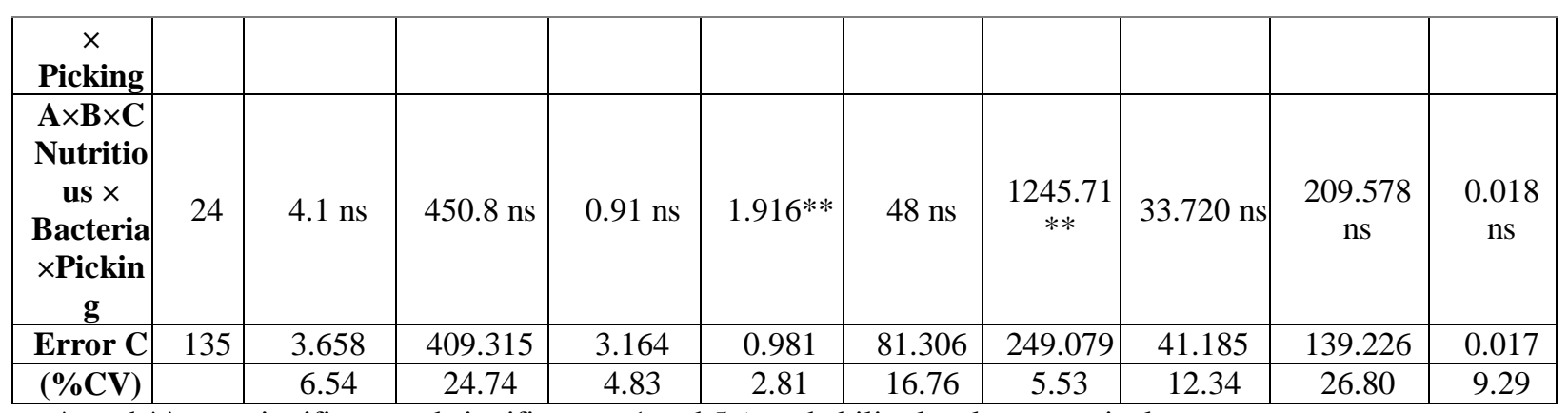

ns, $*$, and ** non-significant and significant at 1 and $5 \%$ probability levels, respectively.

Table 3: Mean comparison of the effect of nutrient foliar application and bacteria for some measured traits of alfalfa

\begin{tabular}{|c|c|c|c|c|c|}
\hline Nutrients & Bacteria & $\begin{array}{c}\text { Chlorophyll a } \\
\text { (mg/g) }\end{array}$ & $\begin{array}{l}\text { Total Chlorophyll } \\
\text { mg/g }\end{array}$ & $\begin{array}{l}\text { Stem wet } \\
\text { weight }\end{array}$ & $\begin{array}{c}\text { Areal fresh } \\
\text { weight }\end{array}$ \\
\hline $\mathrm{Fe}$ & $\begin{array}{c}\text { Rhizobium } 1 \\
\text { Rhizobium } 2 \\
\text { Without } \\
\text { Rhizobium }\end{array}$ & $\begin{array}{l}30.47 \mathrm{c} \\
31.07 \mathrm{c} \\
34.30 \mathrm{~b}\end{array}$ & $\begin{array}{c}49.14 \mathrm{bc} \\
50.27 \mathrm{~b} \\
45.50 \mathrm{de}\end{array}$ & $\begin{array}{c}33.25 \mathrm{e} \\
80.68 \mathrm{ab} \\
47.90 \mathrm{ce}\end{array}$ & $\begin{array}{c}8.243 \mathrm{~d} \\
24.75 \mathrm{ab} \\
12.51 \mathrm{~cd}\end{array}$ \\
\hline $\mathrm{Zn}$ & $\begin{array}{c}\text { Rhizobium } 1 \\
\text { Rhizobium } 2 \\
\text { Without } \\
\text { Rhizobium } \\
\end{array}$ & $\begin{array}{l}30.47 \mathrm{c} \\
40.92 \mathrm{a} \\
32.11 \mathrm{c}\end{array}$ & $\begin{array}{l}51.72 \mathrm{~b} \\
41.93 \mathrm{f} \\
42.74 \mathrm{f}\end{array}$ & $\begin{array}{c}55.49 \mathrm{c} \\
89.44 \mathrm{a} \\
37.39 \mathrm{de}\end{array}$ & $\begin{array}{l}12.65 \mathrm{~cd} \\
25.77 \mathrm{a} \\
10.40 \mathrm{~d}\end{array}$ \\
\hline $\mathrm{Mn}$ & $\begin{array}{c}\text { Rhizobium } 1 \\
\text { Rhizobium } 2 \\
\text { Without } \\
\text { Rhizobium }\end{array}$ & $\begin{array}{l}25.20 \mathrm{~d} \\
41.24 \mathrm{a} \\
31.77 \mathrm{c}\end{array}$ & $\begin{array}{l}36.90 \mathrm{~g} \\
41.62 \mathrm{f} \\
53.98 \mathrm{a}\end{array}$ & $\begin{array}{l}41.50 \text { ce } \\
45.25 \mathrm{ce} \\
54.50 \mathrm{ce}\end{array}$ & $\begin{array}{c}17.87 \mathrm{abcd} \\
12.97 \mathrm{~cd} \\
11.68 \mathrm{~cd}\end{array}$ \\
\hline $\mathrm{Fe}+\mathrm{Zn}+\mathrm{Mn}$ & $\begin{array}{c}\text { Rhizobium } 1 \\
\text { Rhizobium } 2 \\
\text { Without } \\
\text { Rhizobium }\end{array}$ & $\begin{array}{l}30.90 \mathrm{c} \\
39.05 \mathrm{a} \\
28.80 \mathrm{c}\end{array}$ & $\begin{array}{l}50.97 \mathrm{~b} \\
47.67 \mathrm{f} \\
45.11 \mathrm{e}\end{array}$ & $\begin{array}{c}43.63 \mathrm{ce} \\
71.81 \mathrm{~b} \\
43.75 \mathrm{ce}\end{array}$ & $\begin{array}{c}9.422 \mathrm{~d} \\
20.50 \mathrm{abc} \\
10.74 \mathrm{~d}\end{array}$ \\
\hline $\begin{array}{l}\text { Without } \\
\text { Spraying }\end{array}$ & $\begin{array}{c}\text { Rhizobium } 1 \\
\text { Rhizobium } 2 \\
\text { Without } \\
\text { Rhizobium }\end{array}$ & $\begin{array}{l}29.88 c \\
35.84 b \\
29.85 c\end{array}$ & $\begin{array}{c}46.54 \mathrm{de} \\
47.36 \mathrm{~cd} \\
46.07 \mathrm{e}\end{array}$ & $\begin{array}{l}47.30 \mathrm{ce} \\
76.72 \mathrm{ab} \\
51.55 \mathrm{~cd}\end{array}$ & $\begin{array}{l}11.61 \mathrm{~cd} \\
23.43 \mathrm{ab} \\
15.61 \mathrm{bcd}\end{array}$ \\
\hline
\end{tabular}

Means in each column followed by similar letter(s) are not significantly different using Duncan's multiple range tests.

Table 4: Mean comparisons for the effect of nutrient foliar application and picking on performance for some measured traits of alfalfa.

\begin{tabular}{|c|c|c|c|c|c|c|c|}
\hline Nutrients & Picking & $\begin{array}{c}\text { Chlorophyll } \\
\mathbf{a} \\
(\mathbf{m g} / \mathbf{g})\end{array}$ & $\begin{array}{c}\text { Chlorophyl } \\
\mathbf{a} \\
(\mathbf{m g} / \mathbf{g})\end{array}$ & $\begin{array}{c}\text { Total chlorophyll } \\
(\mathbf{m g} / \mathbf{g})\end{array}$ & $\begin{array}{c}\text { Protein } \\
\mathbf{( \% )}\end{array}$ & $\begin{array}{c}\text { Yield } \\
\mathbf{g} / \mathbf{m}^{\mathbf{2}}\end{array}$ & $\begin{array}{c}\text { Stem wet } \\
\text { weight }\end{array}$ \\
\hline \multirow{2}{*}{$\mathrm{Fe}$} & $\begin{array}{c}\text { Picking } \\
1\end{array}$ & $27.94 \mathrm{j}$ & $32.48 \mathrm{c}$ & $50.18 \mathrm{bc}$ & $24.01 \mathrm{e}$ & $47.17 \mathrm{efg}$ & $62.49 \mathrm{ab}$ \\
\cline { 2 - 8 } & $\begin{array}{c}\text { Picking } \\
2\end{array}$ & $31.92 \mathrm{fh}$ & $32.08 \mathrm{c}$ & $51.27 \mathrm{~b}$ & $26.65 \mathrm{e}$ & $\begin{array}{c}53.42 \\
\text { cdef }\end{array}$ & $45.39 \mathrm{de}$ \\
\cline { 2 - 8 } & $\begin{array}{c}\text { Picking } \\
3\end{array}$ & $37.83 \mathrm{c}$ & $35.32 \mathrm{~b}$ & $66.50 \mathrm{de}$ & $40.67 \mathrm{~b}$ & $\begin{array}{c}53.92 \\
\text { cdee }\end{array}$ & $45.39 \mathrm{de}$ \\
\cline { 2 - 8 } & $\begin{array}{c}\text { Picking } \\
4\end{array}$ & $36.10 \mathrm{~d}$ & $35.30 \mathrm{~b}$ & $50.90 \mathrm{~b}$ & $32.25 \mathrm{c}$ & $66.33 \mathrm{ab}$ & $62.49 \mathrm{ab}$ \\
\hline $\mathrm{Zn}$ & $\begin{array}{c}\text { Picking } \\
1\end{array}$ & $30.38 \mathrm{ghi}$ & $32.48 \mathrm{c}$ & $51.73 \mathrm{~b}$ & $24.59 \mathrm{e}$ & $56 \mathrm{bcde}$ & $58.30 \mathrm{bc}$ \\
\hline
\end{tabular}




\begin{tabular}{|c|c|c|c|c|c|c|c|}
\hline & $\begin{array}{c}\text { Picking } \\
2\end{array}$ & 32.42 ef & $41.94 \mathrm{a}$ & $42.94 \mathrm{f}$ & \multicolumn{2}{|c|}{$21.03 \mathrm{e} 61.75 \mathrm{abc}$} & $63.24 \mathrm{ab}$ \\
\hline & \begin{tabular}{|c|} 
Picking \\
3
\end{tabular} & $41.50 \mathrm{~b}$ & $33.12 \mathrm{c}$ & $43.75 \mathrm{f}$ & \multicolumn{2}{|c|}{$47.67 \mathrm{a} 59.50 \mathrm{bcd}$} & $58.30 \mathrm{bc}$ \\
\hline & \begin{tabular}{|c|} 
Picking \\
4
\end{tabular} & $28.97 \mathrm{ij}$ & $42.01 \mathrm{a}$ & $50.70 \mathrm{~b}$ & \multicolumn{2}{|c|}{24.49 e $59.83 \mathrm{bcd}$} & $63.24 \mathrm{ab}$ \\
\hline \multirow[t]{4}{*}{$\mathrm{Mn}$} & \begin{tabular}{|c|} 
Picking \\
1
\end{tabular} & $30.65 \mathrm{gh}$ & $26.24 \mathrm{~d}$ & $37.90 \mathrm{~g}$ & $24.01 \mathrm{e}$ & $\begin{array}{c}53.67 \\
\text { cdef }\end{array}$ & $39.92 \mathrm{e}$ \\
\hline & \begin{tabular}{|c|} 
Picking \\
2
\end{tabular} & $33.88 \mathrm{e}$ & $42.25 \mathrm{a}$ & $42.63 \mathrm{f}$ & $24.65 \mathrm{e}$ & $66.42 \mathrm{ab}$ & 480.25 cde \\
\hline & \begin{tabular}{|c|} 
Picking \\
3
\end{tabular} & 32.71 ef & $32.78 \mathrm{c}$ & $53.99 \mathrm{a}$ & $29.44 \mathrm{~d}$ & $44.75 \mathrm{fg}$ & $39.92 \mathrm{e}$ \\
\hline & \begin{tabular}{|c|} 
Picking \\
4
\end{tabular} & $31.44 \mathrm{fg}$ & $26.17 \mathrm{~d}$ & $37.20 \mathrm{~g}$ & $24.18 \mathrm{e}$ & $\begin{array}{l}53.67 \\
\text { cdef }\end{array}$ & 48.25 cde \\
\hline \multirow[t]{4}{*}{$\mathrm{Fe}+\mathrm{Zn}+\mathrm{Mn}$} & $\begin{array}{c}\text { Picking } \\
1\end{array}$ & 32.63 ef & $32.91 \mathrm{c}$ & $50.98 \mathrm{~b}$ & $24.59 \mathrm{e}$ & $\begin{array}{l}55.50 \\
\text { bcdef }\end{array}$ & $53.75 \mathrm{bcd}$ \\
\hline & \begin{tabular}{|c|} 
Picking \\
2
\end{tabular} & $40.50 \mathrm{~b}$ & $41.06 \mathrm{a}$ & $41.69 \mathrm{f}$ & $40.67 \mathrm{~b}$ & $47.17 \mathrm{~g}$ & $52.38 \mathrm{bcd}$ \\
\hline & \begin{tabular}{|c|} 
Picking \\
3
\end{tabular} & $36.54 \mathrm{~cd}$ & $30.82 \mathrm{c}$ & $46.12 \mathrm{e}$ & $32.25 \mathrm{c}$ & $\begin{array}{c}52.92 \\
\text { cdef }\end{array}$ & $52.75 \mathrm{bcd}$ \\
\hline & \begin{tabular}{|c|} 
Picking \\
4
\end{tabular} & $31.72 \mathrm{fg}$ & $42.01 \mathrm{a}$ & $45.80 \mathrm{e}$ & $24.49 \mathrm{e}$ & $66.25 \mathrm{ab}$ & $52.38 \mathrm{bcd}$ \\
\hline \multirow[t]{4}{*}{$\begin{array}{l}\text { Without } \\
\text { Spraying }\end{array}$} & $\begin{array}{c}\text { Picking } \\
1\end{array}$ & $29.63 \mathrm{hi}$ & $30.90 \mathrm{c}$ & $46.57 \mathrm{de}$ & \multicolumn{2}{|c|}{\begin{tabular}{|l|l|}
$24.03 \mathrm{e}$ & $42.17 \mathrm{efg}$ \\
\end{tabular}} & $70.51 \mathrm{a}$ \\
\hline & \begin{tabular}{|c|} 
Picking \\
2
\end{tabular} & $47.17 \mathrm{a}$ & $35.85 \mathrm{~b}$ & $48.38 \mathrm{~cd}$ & $47.67 \mathrm{a}$ & $\begin{array}{c}50.25 \\
\text { defg }\end{array}$ & $43.88 \mathrm{de}$ \\
\hline & \begin{tabular}{|c|} 
Picking \\
3
\end{tabular} & $33.70 \mathrm{e}$ & $30.85 \mathrm{c}$ & $46.08 \mathrm{e}$ & \multicolumn{2}{|c|}{$29.44 \mathrm{~d} 62.92 \mathrm{abc}$} & $70.51 \mathrm{a}$ \\
\hline & \begin{tabular}{|c|} 
Picking \\
4
\end{tabular} & $33.80 \mathrm{e}$ & 34.84 & $48.10 \mathrm{~cd}$ & $24.18 \mathrm{e}$ & $71.25 \mathrm{a}$ & $43.88 \mathrm{de}$ \\
\hline
\end{tabular}

Means in each column followed by similar letter(s) are not significantly different using Duncan's multiple range tests.

Table 5: Comparison of mean interactions between bacteria and picking for some measured traits of alfalfa

\begin{tabular}{|c|c|c|c|c|c|}
\hline Mn (\%) & Picking & $\begin{array}{c}\text { Stem Wel } \\
\text { Weight }\end{array}$ & Yield $\mathrm{g} / \mathrm{m}^{2}$ & $\%$ Protein & $\begin{array}{c}\text { Areal } \\
\text { fresh } \\
\text { weight }\end{array}$ \\
\hline \multirow{4}{*}{$\begin{array}{c}\text { Rhizobium } \\
1\end{array}$} & Picking 1 & $50.96 \mathrm{c}$ & $45.63 \mathrm{e}$ & $29.92 \mathrm{~b}$ & $15.59 \mathrm{bc}$ \\
\hline & Picking 2 & $35.10 \mathrm{~d}$ & 58.15 bc & $31.38 \mathrm{a}$ & $8.330 \mathrm{e}$ \\
\hline & Picking 3 & $50.96 \mathrm{c}$ & $64.55 \mathrm{ab}$ & $28.65 \mathrm{c}$ & $15.59 \mathrm{bc}$ \\
\hline & Picking 4 & $35.10 \mathrm{~d}$ & $48.90 \mathrm{de}$ & 29.26.bc & $8.330 \mathrm{e}$ \\
\hline \multirow{4}{*}{$\begin{array}{c}\text { Rhizobium } \\
2\end{array}$} & Picking 1 & $68.18 \mathrm{~b}$ & $58.25 \mathrm{~cd}$ & $31.38 \mathrm{a}$ & $19.75 \mathrm{ab}$ \\
\hline & Picking 2 & $78.18 \mathrm{a}$ & $49.90 \mathrm{de}$ & $28.65 \mathrm{c}$ & $23.22 \mathrm{a}$ \\
\hline & Picking 3 & $68.18 \mathrm{~b}$ & $67.75 \mathrm{a}$ & $31.36 \mathrm{a}$ & $19.75 \mathrm{ab}$ \\
\hline & Picking 4 & $78.76 \mathrm{a}$ & $58.40 \mathrm{bc}$ & $27.02 \mathrm{~d}$ & $23.22 \mathrm{a}$ \\
\hline \multirow{2}{*}{$\begin{array}{l}\text { Lack of } \\
\text { Inculation }\end{array}$} & Picking 1 & $51.84 \mathrm{c}$ & $56.15 \mathrm{~cd}$ & $29.92 \mathrm{~b}$ & $13.89 \mathrm{de}$ \\
\hline & Picking 2 & $38.60 \mathrm{~d}$ & $55.60 \mathrm{~cd}$ & $31.36 \mathrm{a}$ & $10.50 \mathrm{de}$ \\
\hline
\end{tabular}




\begin{tabular}{|c|c|c|c|c|c|}
\hline & Picking 3 & $51.84 \mathrm{c}$ & $49.10 \mathrm{de}$ & 27.05 & $13.88 \mathrm{~cd}$ \\
\cline { 2 - 6 } & Picking 4 & $38.60 \mathrm{~d}$ & $65.50 \mathrm{ab}$ & $29.26 \mathrm{bc}$ & $10.50 \mathrm{de}$ \\
\hline
\end{tabular}

Table 6: Mean comparisons for the effect of foliar application of nutrients, bacteria and picking on Alfalfa protein

\begin{tabular}{|c|c|c|c|c|c|}
\hline Nutrients & Bacteria & Picking 1 & & Diclking 3 & Dirlring \\
\hline & & & & & \\
\hline \multirow[t]{3}{*}{$\mathrm{Fe}$} & Rhizobium 1 & $24.08 \mathrm{i}-\mathrm{n}$ & $24.60 \mathrm{i}-\mathrm{m}$ & $24.08 \mathrm{i}-\mathrm{n}$ & $24.60 \mathrm{i}-\mathrm{m}$ \\
\hline & Rhizobium 2 & $25.02 \mathrm{i}-1$ & $25.60 \mathrm{i}$ & $25.02 \mathrm{i}-1$ & $25.60 \mathrm{i}$ \\
\hline & $\begin{array}{c}\text { Without } \\
\text { Rhizobium }\end{array}$ & $22.92 \mathrm{mn}$ & $23.58 \mathrm{k}-\mathrm{n}$ & $22.92 \mathrm{mn}$ & $23.58 \mathrm{k}-\mathrm{n}$ \\
\hline \multirow{3}{*}{$\mathrm{Zn}$} & Rhizobium 1 & $24.23 \mathrm{i}-\mathrm{n}$ & $24.90 \mathrm{i}-1$ & $24.23 \mathrm{i}-\mathrm{n}$ & $24.90 \mathrm{i}-1$ \\
\hline & Rhizobium 2 & $25.27 \mathrm{i}-\mathrm{n}$ & $25.35 \mathrm{i}-1$ & $25.27 \mathrm{ijk}$ & $25.35 \mathrm{ij}$ \\
\hline & $\begin{array}{c}\text { Without } \\
\text { Rhizobium }\end{array}$ & $22.60 n$ & $23.70 \mathrm{j}-\mathrm{n}$ & $22.60 n$ & $23.70 \mathrm{j}-\mathrm{n}$ \\
\hline \multirow{3}{*}{$\mathrm{Mn}$} & Rhizobium 1 & $45.50 \mathrm{c}$ & $50 \mathrm{a}$ & $45.50 \mathrm{c}$ & $50 a$ \\
\hline & Rhizobium 2 & $38 \mathrm{~d}$ & $47.75 \mathrm{~b}$ & $38 \mathrm{~d}$ & $47.75 \mathrm{~b}$ \\
\hline & $\begin{array}{c}\text { Without } \\
\text { Rhizobium }\end{array}$ & $38.50 \mathrm{~d}$ & $45.25 \mathrm{c}$ & $38.50 \mathrm{~d}$ & $45.25 \mathrm{c}$ \\
\hline \multirow{3}{*}{$\mathrm{Fe}+\mathrm{Zn}+\mathrm{Mn}$} & Rhizobium 1 & $31.20 \mathrm{f}$ & $33.25 \mathrm{e}$ & $31.20 \mathrm{f}$ & $33.25 \mathrm{e}$ \\
\hline & Rhizobium 2 & $29.38 \mathrm{~g}$ & $32.88 \mathrm{e}$ & $29.38 \mathrm{~g}$ & $32.88 \mathrm{e}$ \\
\hline & $\begin{array}{c}\text { Without } \\
\text { Rhizobium }\end{array}$ & $27.75 \mathrm{~h}$ & $30.63 \mathrm{fg}$ & $27.75 \mathrm{~h}$ & $30.63 \mathrm{fg}$ \\
\hline \multirow{3}{*}{ Control } & Rhizobium 1 & $24.58 \mathrm{i}-\mathrm{m}$ & $24.13 \mathrm{i}-\mathrm{n}$ & $24.58 \mathrm{i}-\mathrm{m}$ & $24.13 \mathrm{i}-\mathrm{n}$ \\
\hline & Rhizobium 2 & $25.58 \mathrm{i}$ & $25.25 \mathrm{ijk}$ & $25.58 \mathrm{i}$ & $25.25 \mathrm{ijk}$ \\
\hline & $\begin{array}{c}\text { Without } \\
\text { Rhizobium }\end{array}$ & $23.33 \mathrm{lmn}$ & $23.17 \mathrm{mn}$ & $23.33 \mathrm{lmn}$ & $23.17 \mathrm{mn}$ \\
\hline
\end{tabular}

Means in each column followed by similar letter(s) are not significantly different using Duncan's multiple range tests.

Table 7: Comparison of mean interactions between micronutrients, picking, and bacteria on total shrub

\begin{tabular}{|c|c|c|c|c|c|}
\hline Nutrients & Bacteria & Picking 1 & Picking 2 & Picking 3 & Picking 4 \\
\hline \multirow{2}{*}{ Fe } & Rhizobium 1 & $76.07 \mathrm{abc}$ & $77.22 \mathrm{abc}$ & $76.38 \mathrm{ab}$ & $79.26 \mathrm{a}$ \\
\cline { 2 - 6 } & Rhizobium 2 & $67.39 \mathrm{j}-\mathrm{m}$ & $62.55 \mathrm{nop}$ & $69.53 \mathrm{~h}-\mathrm{m}$ & $71.56 \mathrm{~d}-\mathrm{j}$ \\
\cline { 2 - 6 } & $\begin{array}{c}\text { Without } \\
\text { Rhizobium }\end{array}$ & $74.46 \mathrm{~b}-\mathrm{f}$ & $73.85 \mathrm{c}-\mathrm{g}$ & $75.97 \mathrm{abc}$ & $75.45 \mathrm{a}-\mathrm{d}$ \\
\hline \multirow{2}{*}{ Zn } & Rhizobium 1 & $68.32 \mathrm{i}-\mathrm{m}$ & $69.38 \mathrm{~h}-\mathrm{m}$ & $70.47 \mathrm{f}-\mathrm{k}$ & $71.18 \mathrm{e}-\mathrm{k}$ \\
\cline { 2 - 6 } & Rhizobium 2 & $70.51 \mathrm{f}-\mathrm{k}$ & $71.31 \mathrm{e}-\mathrm{j}$ & $73.05 \mathrm{c}-\mathrm{h}$ & $75.88 \mathrm{abc}$ \\
\cline { 2 - 6 } & $\begin{array}{c}\text { Without } \\
\text { Rhizobium }\end{array}$ & $55.38 \mathrm{~s}$ & $56.97 \mathrm{rs}$ & $57.42 \mathrm{rs}$ & $60.17 \mathrm{o}-\mathrm{r}$ \\
\hline \multirow{2}{*}{$\mathrm{Mn}$} & Rhizobium 1 & $37 \mathrm{y}$ & $39.25 \mathrm{wxy}$ & $40.75 \mathrm{v}-\mathrm{y}$ & $46 \mathrm{u}$ \\
\hline
\end{tabular}




\begin{tabular}{|c|c|c|c|c|c|}
\hline \multirow{2}{*}{ Fe+Zn+Mn } & Rhizobium 2 & 37.5 xy & $40 \mathrm{wxy}$ & $44.50 \mathrm{uv}$ & $50.75 \mathrm{t}$ \\
\cline { 2 - 6 } & $\begin{array}{c}\text { Without } \\
\text { Rhizobium }\end{array}$ & $38 \mathrm{xy}$ & $45.75 \mathrm{u}$ & $41.25 \mathrm{vwx}$ & $42.25 \mathrm{uvw}$ \\
& Rhizobium 1 & $60.70 \mathrm{o}-\mathrm{r}$ & $62.13 \mathrm{n}-\mathrm{q}$ & $63.25 \mathrm{no}$ & $65.63 \mathrm{mn}$ \\
\cline { 2 - 6 } & Rhizobium 2 & $58.75 \mathrm{p}-\mathrm{s}$ & $57.97 \mathrm{rs}$ & $62.75 \mathrm{nop}$ & $66 \mathrm{lmn}$ \\
\cline { 2 - 6 } & $\begin{array}{c}\text { Without } \\
\text { Rhizobium }\end{array}$ & $55.95 \mathrm{~s}$ & $58.80 \mathrm{p}-\mathrm{s}$ & $58.50 \mathrm{qrs}$ & $59.25 \mathrm{p}-\mathrm{s}$ \\
\hline Control & Rhizobium 1 & $73.69 \mathrm{c}-\mathrm{g}$ & $69.43 \mathrm{~h}-\mathrm{m}$ & $75.68 \mathrm{a}-\mathrm{d}$ & $77.25 \mathrm{abc}$ \\
\cline { 2 - 6 } & Rhizobium 2 & $65 \mathrm{~d}-\mathrm{r}$ & $75.63 \mathrm{a}-\mathrm{d}$ & $73.13 \mathrm{c}-\mathrm{h}$ & $75.13 \mathrm{a}-\mathrm{e}$ \\
\cline { 2 - 6 } & $\begin{array}{c}\text { Without } \\
\text { Rhizobium }\end{array}$ & $67.06 \mathrm{klm}$ & $67.85 \mathrm{i}-\mathrm{m}$ & $67.83 \mathrm{i}-\mathrm{m}$ & $70.10 \mathrm{~g}-\mathrm{l}$ \\
\hline
\end{tabular}

Means in each column followed by similar letter(s) are not significantly different using Duncan's multiple range test.

\section{CONCLUSION}

In general, the results of this study indicate, Bacterial inoculation has a significant effect on chlorophyll content and yield and also affects protein percentage. Increasing growth parameters following rhizobium inoculation is one of the important mechanisms of the plant for greater resistance to stress, more root growth than The aerial part after stabilization means more distribution of photosynthetic material to the underground organs and as a result more root growth can help absorb water and nutrients, inoculation as a helper bacterium and compatible with rhizobia improves nodes and better stabilization Nitrogen is converted by rhizobia. Overall, it was observed that inoculation with Rhizobium Melilloti and China II had the highest yield in terms of forage in southeastern Iran.

\section{REFERENCES}

Abdel-Rahman, E. (2013). Impact of chicken manure and sowing methods on alfa alfa (Medicago Satival) Growth, forage yield and some quality altributes, Int j. sudan Res, 3(1), 35-54

Abusuwar, A., \& Daur, I. (2015). Effect of seed pelletting with organic manures and Rhizobia on the performance of two alfalfa cultivars grown in saline environment. Legume Research-An International Journal, 38, 513-518

Ahemad, M., \& khan Khan, M. (2011). Functional Aspects of Plant Growth Promoting Rhizobacteria: Recent Advancements. Insight Microbiology, 1, 39-54

Amri, S., Parsa, M., \& Ganjali, A. (2010). The effect of drought stress on morphological traits and yield Components of Cicer arientinum in different stages \& Phonology under greenhouse conditions. IRANIAN JOURNAL OF FIELD CROPS RESEARCH, 8(1), 157-166,

Aslani, Z., Hassani, A., Rasouli Sadaghiani, H., barin, M., \& Sefidkon, F. (2011). The effect of two fugi species of micorrizo on growth, Chlorophy contents and P absorption in ocimum basilicum L under drought stress Conditions. Iranian Journal of Medicinal And Aromatic Plants Fall, 27, 3(53), 471-486.

Delic, D., stajkovic-Srbinovic, O., \& kenezevie vukcevic, J. (2016). Alfa Alfa LMedicago satival.) and sinorhizobium Meliloti: prospects of using rbizobial inoculants in Serbia. Bot. serbica, 40(1), 13-19 
Delić, D., Stajković-Srbinović, O., \& Knežević-Vukčević, J. (2016). Alfalfa (Medicago sativa L.) and Sinorhizobium meliloti: prospects of using rhizobial inoculants in Serbia. Botanica Serbica, 40(1), 13-19.

Dordas, C. (2009). Foliar Application of Manganese Increases Seed Yield and Improves Seed Quality of Cotton Grown on Calcareous Soils. Journal of Plant Nutrition, 32(1), 160-176

Ensiye, A., Razmjoo, J., \& Zahedi, M. (2018). Effect of salt stress on Growth and Ion accumulation of alfalfa (Medicago sativa L.) cultivars. Journal of Plant Nutrition, 41(7), 818-831

Etesmai, H., \& Alikhani, H. (2011). Evaluation of plant growth hormines production (auxins) ability Iranian soils rhizobial strains and effect of superior strains application on wheat growth indexes and the loss of chemical fertilizers. Agronomy Journal (Pajouhesh and Sazandegi), 92(6), 53-62

Fukami, J., Cerezini, P., \& Hungria, M. (2018). Azospirillum: benefits that go far beyond biological nitrogen fixation, AMB Expr 8, 73.

Gunes, A., Adak, E., Bagci, N., \& Eraslan, F. (2008). Effect of drought stress implemented at pre- or post-anthesis stage on some physiological parameters as screening criteria in chickpea cultivars. Russ J Plant Physiol, 55, 59-67 (2008).

Hadi, H., Daneshian, J., Asgharzadeh, A., Jonouxi, P., Ghooshehi, F., \& Nasri, M. (2009). EFFect of free and symbiotic nitrogen fixing bacterial co-inoculation on seed and seedling of soybeen seeds produced under deficit water condition Agroecol, 4(1), 53-64

Hu, X., Tanaka, A., \& Tanaka, R. (2013). Simple extraction methods that prevent the artifactual conversion of chlorophyll to chlorophyllide during pigment isolation from leaf samples. Plant Methods, 9(19).

Khalil, S., Nahed, A., Azizi, L., \& Bedour, H. (2010). Effect of Water Stress, Ascorbic Acid and Spraying Time on Some Morphological and Biochemical Composition of Ocimum basilicum plant. Journal of American Science, 6(12), 33-44.

McKenzie, R., McKenzie, R., \& Kryzanowski, L. (2015). Fertilizer requirement of irrigated alfalfa. Alberta Agricultural Research Institute. Project 94M626, 60, 1999

Sadras, V., \& Lawson, C. (2012). Contribution of summer rain fall and nitrogen to the yield and water use efficienq of whea in mediterr anean - type environments of south Australia-eur. J. Agron, 3(6), 41-54

Taherkhani, M., Mohammadi, M. Mir Hadi, H., \& Shari fahad, A. (2009). The effects of inoculating bacteria Strains (R. leguminosarum. phasedi) on nitrogen fixation in Phaseolus vulgaris cultivars. Journal of agricultural novel Know ledge, 14(1), 23-36

Tiedje, J., Sexstone, A., Myrold, D., \& Robinson, J. (1982). Denitrification: ecological niches, competition and survival. Antonie Van Leeuwenhoek, 48(6), 569-583

Yang, Y., \& Wang, Y., \& Zhang, H. (2013). The response of ginseng grown on on farmland to foliat - applied iron. Zinc, manganese and copper. Ind. Crops prod, 45(8), 388-394 